\title{
Effects of Dicto-Comp and Dictation on the Writing Skill of Female Adult Iranian EFL Learners
}

\author{
Rahil Adel ${ }^{1} \&$ Mahmood Hashemian ${ }^{1}$ \\ ${ }^{1}$ Department of Foreign Languages, Isfahan (Khorasgan) Branch, Islamic Azad University, Isfahan, Iran \\ Correspondence: Mahmood Hashemian, Islamic Azad University, Isfahan (Khorasgan) Branch, Isfahan, Iran. Tel: \\ 98-913-266-3269. E-mail: m72h@hotman.com
}

Received: June 10, 2015 Accepted: September 15, 2015 Online Published: September 18, 2015

doi:10.5539/elt.v8n11p17 URL: http://dx.doi.org/10.5539/elt.v8n11p17

\begin{abstract}
This study was an attempt to clarify and remind L2 learners/teachers of 2 kinds of writing: dicto-comp and dictation. We explored the effect of controlled writing on the accuracy of the writing of adult Iranian EFL learners. Prior to the study, the homogeneity of 30 adult EFL learners was checked through an OPT test. Thirty participants were assigned to 210 one-hour sessions: Group A via dicto-comp and Group B via dictation. Following this practice, the participants in both groups were asked to write texts as the posttest about similar topics to the one of the pretest. Results indicated that the participants working in the dictation wrote more accurately than those who wrote in dicto-comp format; however, but both dictation and dicto-comp had positive effects on the writing of the participants.
\end{abstract}

Keywords: writing, controlled writing, dicto-comp, dictation, accuracy

\section{Introduction}

Believing that the process of learning L2 writing is important, both for youth and adults, there is no wonder that there has been much research on learning and improving writing in an L2 among youth and adults (e.g., Barrent, 1989; Eisterhold, 1990; Janopoulos, 1989; Krashen, 2003). Considering the impact of writing on the process of learning a second language, Chastain, (1980) believes in changing the approaches and methods of teaching this important skill in L2 classes. He points out that improving students' attitudes toward writing is very important; and controlled writing could be a good approach to improve writing skill of second language learners.

One of the main proponents of controlled writing is Raimes (1983) who states that "unlike free writing, controlled writing takes place when learners are supplied with a great deal of the content and form, for example, an outline to complete, a paragraph to manipulate, a model to follow, or a passage to continue" (p. 95). Raimes argues that controlled writing is a practical process of "reinforcing grammar, vocabulary, and syntax in context. In addition, as the students write the passages, they are using the conventions of written English, such as indentation, punctuation, and connecting words, and spelling" (p. 97). He believed controlled writing is a parallel writing in which learners "read and study a passage and then write their own on a similar theme, using as a guide the vocabulary, sentence structure, cohesive devices, and organization of the model passage" (p. 109).

Owens (1970) believes that via controlled writing, teachers provide enough correct forms and grammatical examples in every dictation. Paulston (1992) argues that controlled writing is easy to prepare and also teachers can correct it fast. He adds that controlled writing provides a chance for practicing writing with different purposes.

Oller (1979) believes that the reason for considering dictation as a successful controlled writing is that in dictation, learners can show what they really know about the L2 and how they use it in their real life. Oller also emphasized that dictation is successful because listeners understand what they hear and then combine that with their own idea, and finally they produce a piece of writing; they do it by recalling the previous knowledge in their mind. Stansfield (1985) reports that "more than 50 studies of dictation were conducted in the 1970s, and these findings were invariably favorable" (p. 26). Takeuchi (1997) did an experiment of dictating on 207 English language learners in Japan. Learners were given the dialogues in movies for more than 13 weeks. Finally, he observed the big change in writing of those students. Takeuchi concluded that his experiment "proves that dictation is effective in foreign language teaching" (p. 62).

Krashen (2003) believes in the use of dictation and controlled writing in university classrooms; because in using 
this method for improving writing, considering skill and the range of the class is not needed. The use of dictation can provide some benefits for university EFL classroom management, as well. Dictation can be used successfully regardless of the class size or the range of skill. Because here they work together and use grammatical text to complete the dictation. Mezirow (1991) worked on some women returned for higher education and focused on the idea of perspective transformation. Mezirow suggests a theory of transformative learning "that can explain how adult learners make sense or meaning of their experiences, the nature of the structures that influence the way they construe experience, the dynamics involved in modifying meanings, and the way the structures of meaning themselves undergo changes when learners find them to be dysfunctional" (Mezirow, 1991, p.12). Being experienced is one of the significant features of adults. As Lindeman states "experience is the adult learners' living textbook" $(1936$, p. 7) and that adult education was, therefore, "a continuing process of evaluating experiences" (p. 85).

Birdsong and Mollis (2001) indicated that those learner who start learning L2 at early ages, learn better, and this age period is called critical period from 5-15 years. They believe learning L2 in this period happens more proficiently and after that learning is not really native like. Lenneberg (1967) explained comparing young and older language learners indicates, before puberty, language acquisition happens automatically, but after that learners need to be taught and learn the language, learning doesn't happen just through exposure to the target language and it occurs consciously.

Graham and Perin (2007) claim that reading and writing are complementary skills, that is, by proving in one of these two skills, the L2 learner can act in the other skill better, but it doesn't mean a good reader is necessarily a good writer. The other benefit of writing summaries after reading is helping student writers adjust themselves with different texts and subjects in different fields. Research indicates that different text structures place distinct demands on readers' comprehension. Good readers adjust to these variations (Dickson, Kamenui, \& Simmons, 1998). Spelling instruction has a moderate and consistent effect on improving students' word reading (Graham \& Hebert, 2010). There is evidence that direct instruction with adequate practice in handwriting can help in the prevention of writing disabilities among young students (Baker, 2003; Graham, 2007). Baker believed lack of fluency in spelling and handwriting can contribute to a student's self-perception of their overall writing ability and impact motivation. Sentences have a positive impact on word reading skills. Although some researchers and authors identify up to seven steps in the writing process, the Indiana Department of Education identifies these common five steps: (1) Prewriting (Planning), (2) Drafting, (3) Revising, (4) Proofreading (Editing), and (5) Publishing. These five steps provide structure and a logical sequence for the development of written work, from draft to finished product. Gammill (2006) states that "writing to learn, to build comprehension and understanding, is a method any teacher in any area can implement and use successfully with students" (p. 755). Because of lots of emphasizing on the process of learning how to write, the importance of the help of writing for learning have been forgotten (Frey \& Fisher, 2007)

On the other hand, writing to learn is writing for comprehension and provides a chance to remember, clarify, and question what they have read, and it give students an opportunity for reviewing and having higher comprehension. Bangert-Drowns, Hurley, and Wilkinson (2004) found that when students write to learn they can improve their understanding of the content and their knowledge of language.

Aukerman (2006) said that "Students can find their way to text-based critical thinking when an astute teacher provides time for exploring texts through supporting interpretations. "Interpreting a text should involve making decisions about how different aspects of the text fit (or fail to fit) with the hypotheses a reader has begun to generate" (p. 37). According to Vacca and Vacca (2004), summarizing what learners read can improved comprehension. They state "writing facilitates learning by helping students explore, clarify, and think deeply about the ideas and concepts they encounter in reading" (p. 353). As Hurst, Fisk, and Wilson (2006) state, after reading the text, answering to some questions and revisiting and having a discussion about the text, can help increase their comprehension.

Gammill (2006) states "writing to learn, to build comprehension and understanding, is a method any teacher in any area can implement and use successfully with students" (p. 755). Brown (2000) suggested that "as a facilitator, the teacher offers guidance in helping students to engage in the thinking process of composing but, in a spirit of respect for student opinion, must not impose his or her own thoughts on students writing" (p. 340). "Writing to display one's knowledge is a fact of life in the classroom, and by getting your students to perform well in display writing exercises, they can learn skills that will help them to succeed in further academic pursuits" (Brown, 2000, p. 340). "In adult education and survival English classes, filling out forms and questionnaires may be as sophisticated as students' need get" (p. 339). Brandenburg (2002) noted that "by forcing students to demonstrate their comprehension through writing, they learned to pinpoint any confusion, 
compare and contrast mathematical methods, and ultimately deepened their understanding and retention" (p. 68).

Graham and Hebert (2010), Graham and Perin, (2007 believe in the important role of writing in the success of language learners. According to Olsen and Land (2007), there are several purposes for writing included writing for persuading, communicating, informing, describing; good student writers should have the ability to write for all these purposes. They also believe if learners learn to clarify goals, use their prior knowledge, ask and answer questions, get a gist of the text they read and, finally evaluate their own text, they will have meaningful texts.

Phillips (2011) suggests some activities for practicing writing with the help of reading done before. He states that students can read first and then write a summary of the text they've read or they can write their feeling about the story or text. Further, he adds they can use writing in scientific fields and mathematics; they see an experiment then they report it. He believes writing as a tool for learning and communicating.

Grahamn and Perin (2007) claim learning to write should start with learning to read. Learning both reading and writing must be systematic. They introduce writing as the flip side of reading and that reading and writing improve beside each other and together. Graham and Harris (2009) mention the relation between writing and reading by introducing (block of writing) that emphasizes writers need knowledge of content as much as knowledge of prior knowledge. They explain writers should have skill for planning writing and use correct process for revising. They should have skill of processing, spelling, making sentences and paragraphs. Writers should have knowledge of content. And finally they should enjoy writing. People need writing in their life and education. It is a necessary and basic skill (Graham \& Herbert, 2010). They found that increasing the length of the time that learners write effects their abilities to write well. When learners read texts more and more, they really get information about the process of writing and making texts, they can pay attention to both content and strategies of writing.

According to Shanahan (2006), for being a good writer, the learner should be good at word processing, understanding the convention of writing, spelling, linguistic knowledge hand writing. He also believes having knowledge about how to write and how to read is helpful for writers because when they think about what they know and understand about writing, they can write well. Graham and Harris (2009), in addition, proved that for having better writing skill, learners should practice more and more. Brown (2000) said "writers must learn how to remove redundancy, how to combine sentences, how to make references to other elements in a text, how to create systematic and lexical variety, and much more" (p. 342).

Writing development can be effected by motivation (Graham \& Harris, 2009). According to Graham and Hebert (2010) believe that motivation is created when the learner finds confidence in himself and herself for producing a piece of writing. Motivation exists when one can write, can transform his or her thought in to written form. Brown (2000) believes time limitation in practicing writing and educational writing courses can be a problem and increases stress. "With sufficient training in process writing, combined with practice in display writing, you can help your students deal with limitation (Brown, 2000, p. 341). Writing after reading has been emphasized by Graham and Hebert (2010) also emphasizes the importance of writing in response to reading. They believe it can increase their comprehension.

Graham and Perin (2007) Graham and Hebert (2010) claimed that writing after reading increases learner's comprehension it also can motivate and give enough desire to write summaries after reading, it also engages, encourages and enhances students' desire to write. In addition they believed writing after reading not only increases their desire for writing but also increases the motivation for reading more. Graham and Hebert (2010) indicated learners can have more understanding after reading scientific and social texts when they have a report in written form. Here the role of the teacher is to prepare learners by giving instruction and making them to summarize, make question, answer them and also take notes about the text. They also added it is very useful when learners make and answer the questions before and during and after reading the texts in this way understanding the strategies of making question happens well.

Graham and Herbert (2010) state when students take notes while reading or listening, their comprehension of what they read increases because note taking helps the learners to remember in other words it is supportive for writing, and by working on spelling, learners can identify words, and the sound of letter and combing sentences. They also provide routine steps that support writing skills. They include (1) Combining smaller units of writing (sentences or paragraphs), (2) creating more complex units. Graham and Perin (2007) start the process of writing with working on sentence level and go ahead with combining sentences to make paragraphs and finally writing multi paragraphs.

Dornyei (2001) believes in motivation as one of the most difficult matters in classes. Masgoret and Gardner (2003) suggest the factors that affect students' motivation. First of all L2 learners should be able to be aware of 
their achievement. They should be independent and understand how important it is. Learner should feel fun and engaged in activities through a good methodology. Having close relationship in class and the society is helpful for having motivated classes. He adds the culture of learners in the class also influence the motivation. Masgoret and Gardner concluded that "motivation is more highly related to second language achievement than other factors" (p. 205).

\section{Controlled Writing (Dicto-Comp and Dictation)}

The previous studies explored how dicto-comp or dictation could progress the writing skill of young L2 learners. The focus of the previous results has been mainly on the young L2 learners; therefore, this study was an attempt to identify the effect of dicto-comp and dictation on the writing skill of adults who are over 55 years old. Controlled writing as a device which helps L2 learners to promote their writing skill is considered to be of three kinds: guided writing, dicto-comp, and dictation. The current research aimed at comparing the effect of the dicto-comp and dictation on the writing of adults regarding the accuracy level by presenting the following questions:

1) Is there any difference between the degree of accuracy of texts written by Iranian adult EFL learners practicing through dictation and those learners practicing through dicto-comp?

2) Dose dicto-comp writing influence the degree of accuracy of the writing skill of adult Iranian EFL learners?

3) Does dictation writing influence the degree of accuracy of the writing skill of adult Iranian EFL learners?

\section{Conducting an Experiment}

In order to answer the questions and find the effect of using controlled writing on the writing skill of adult L2 learners, an experiment was done.

\subsection{Method}

\subsubsection{Participants}

The participants for this study were selected from the population of a center established in 2005 with the aim of preparing a specific community for adults over 55 years old interested in social activities. The rationale behind choosing the participants from this institute was that this institute was the only one founded only for the adults and the researcher could have a random selection among the adult 12 learners who were over 55 years old. Some of the participants were retired from banks or the educational system of schools; some were home makers but educated; and some were not highly educated, but very eager to learn English as their L2.

The population from which the sample group was selected did not have the same educational background of high school or university, so an Oxford Placement Test (OPT) was distributed among 40 students in three different grades. The reason for conducting the OPT was that some of the students were attending the same class and studying the same books, but the level of their knowledge was not the same because of their previous experience in learning English. By using the OPT, the essential homogeneity of their proficiency for attending in this study was measured. The OPT test was given to 40 students who were all female, native speakers of Persian and learned English as an L2. After the placement test, 30 students were selected as the sample group. The scores of the selected participants in the placement test were ranged from 120 to 134 which included the preintermediate level.

The sample population was divided into two experimental groups: Group A and Group B. From the 30 preintermediate students selected after conducting the OPT, 15 were randomly assigned to each experimental group. The reason why there were two experimental groups was because the effects of using two kinds of controlled writing (i.e., dicto-comp and dictation) on the writing skill of the participants in two separate groups were to be compared.

\subsubsection{Materials and Procedure}

To run this study and collect data to compare the effect of dicto-comp and dictation on adults' writing, the applied instruments in both experimental groups included: First, prior to the study, the OPT consisting of 100 items was used to measure the participants' language proficiency. The level considered for this study was preintermediate. Second, for the pretest, all the participants were asked to write about the same topic of general interest. The rationale behind this was to provide the study with enough data to compare the participants' writing before and after the experiment. Afterwards, 30 texts were collected, corrected, and the numbers of wrong items in every individual's text were compared, the reason of which was to observe the possible changes in the numbers of errors on the pretest and the posttest as well as the effect of applying dicto-comp and dictation on the writing skill of the participants. 
During the study, 10 short stories were chosen from a story book named Steps to Understanding. This book has four parts, each of which containing 10 stories for elementary, preintermediate, intermediate, and advanced L2 learners. Because the participants were at the preintermediate level, 10 stories in the preintermediate level of the book were read to the participants in 10 sessions.

Before starting this study, a pretest was conducted. A topic of general interest was chosen, and all the participants in both experimental groups were asked to write a text of 150 words about the topic. The participants were asked to write without the help of the teacher, dictionary and other participants. The texts were corrected by the same rater, and the number of errors was kept in order to compare with the number of errors in the texts that would be written by the participants for the posttest. Afterwards, during 10 one-hour sessions, both experimental groups with 30 adult learners were exposed to continual writing.

In Group A, dicto-comp, and in Group B, dictation were used as the controlled writing. According to Ilson (1962) and Riley (1972), in dictation after listening to the teacher reading the text, the learners should remember a phrase of some words and then write the whole phrase they have heard, but in dicto-comp, the learners have to remember the idea of the whole text read and write it in many words as accurately as they can.

In Group A, the teacher read each text several times in a specific speed. The participants were allowed to take notes of the whole text. First, they listened carefully; then, they could take notes; for the last time, they could listen and correct their notes. The teacher read each text within the same specific speed. As the participants had to listen carefully and take notes, they needed high concentration, so they were asked not to interrupt the teacher during reading the text and just listen and take notes. They could remove their misunderstanding or any ambiguity in the text when the teacher was done with reading the text for the second or third time. Then, after three times, the participants started writing. They could use their notes to write complete sentences and phrases. Also, the participants could make sentences by using their own ideas to express the gist of each read text.

In Group B, the teacher read the same texts which were read in Group A. Each text was read twice and with the same speed. The participants were supposed to listen carefully, and when the teacher paused after each short, completed sentence or phrase, they could write the exact sentence. The simple sentences were read completely, twice immediately after each other. The complete sentences were divided into two parts, and each part was read twice separately by the teacher. The texts which were read in Group A were exactly the same texts which were read in Group B, and the reader was the same during the study. The rater was the same for both groups. The speed of reading was specific and the same for both Groups A and B.

\subsubsection{Data Analysis}

The present study, therefore, employed a pretest-treatment-posttest design to investigate the possible effects of dictation and dicto-comp on the writing accuracy of the participants. From among the 40 elderly ladies attending English classes at a community center, a sample of 30 preintermediate L2 learners was chosen after the administration of the OPT. The selection took place based on the learners' OPT scores: Those who obtained a score between 1 standard deviation above and below the mean were chosen to take part in this study. The sample was, then, randomly divided into Groups A and B. A writing pretest was given to both groups of learners, each group was exposed to the related treatment, and finally the groups sat for the posttest. The written texts in the pretest, the written texts in the posttest, and the written texts during the study were compared in term of accuracy. In Oxford Dictionary, accuracy is defined as the state of being correct and exact and without errors. The identified errors in this study included errors of tense, using wrong irregular past tense, using or omitting third person singular $s$, plural $s$, using or omitting ing wrongly for present continuous tense.

In this study, independent samples $t$ test was used to compare the tests in both experimental groups A and $\mathrm{B}$. The SPSS software was used to check the statistical results of the texts in Groups A and B. This study was launched to observe the relationship between the writing of adults and controlled writing. To investigate if there was any noticeable difference between the effect of dicto-comp and dictation on the writing skill of the participants, the collected data were analyzed in the following phases.

First, the texts written by the participants in the first session as the pretest in both Groups A and B were compared. This comparison was done in term of accuracy. The results of the collected texts were analyzed through independent samples $t$ test.

Second, the texts written by the participants in the last session as the posttest in both Groups A and B were compared. This comparison was done in term of accuracy. The results of texts were analyzed through independent samples $t$ test.

Third, the texts written in the first and last sessions were compared in both groups A and Group B separately. The 
rationale behind this was to reveal the effect of using dicto-comp and dictation on the writing skill of the participants in both Groups A and B. The percentage of development in each experimental group was calculated.

\subsubsection{Results of the Pretest}

The purpose of the pretest was to make certain that Groups A and B were at a roughly equal level of writing accuracy at the beginning of the study. An independent samples $t$ test was used to help achieve the purpose of the pretest. The mean score of Group A $(M=16.73)$ was only slightly greater than the mean score of Group B $(M=$ 16.54). This difference did not seem to be significant, but to ascertain whether it was or not, the $p$ value under the Sig. (2-tailed) column in the $t$ test table had to be checked.

There was not a statistically significant difference in the pretest scores for Group A $(M=16.73, S D=2.08)$ and Group B $(M=16.54, S D=1.88), t(28)=.27, p=.78$ (2-tailed). This was so because the $p$ value was greater than the specified level of significance (i.e., .05). If the $p$ value were less than the alpha level (i.e., the level of significance), the conclusion would be that the two groups were not at the same level of writing accuracy prior to the experiment.

\subsubsection{Results for the First Research Question}

As previously mentioned, the first research question of the study asked whether there was a significant difference between the degree of accuracy of texts written by Iranian adult EFL learners practicing through dicto-comp and those learners practicing through dictation. The posttest results obtained from the two groups were once again compared via an independent samples $t$ test. Tables 1 and 2 present the results of this analysis:

Table 1. Descriptive statistics for comparing Group A and Group B posttest scores

\begin{tabular}{llllll}
\hline & Groups & $N$ & Mean & Std. Deviation & Std. Error Mean \\
\hline Posttest & A & 15 & 15.53 & 2.58 & .66 \\
& B & 15 & 17.13 & 1.50 & .38 \\
\hline
\end{tabular}

The mean score of Group A $(M=15.53)$ was less than the mean score of Group B $(M=17.13)$. To check this whether this difference was statistically significant or not, one should examine the $p$ value under the Sig. (2-tailed) column in the $t$ test table:

Table 2. Results of the independent samples $t$ test for comparing the EG and TG posttest scores

\begin{tabular}{|c|c|c|c|c|c|c|c|c|c|c|}
\hline & & \multicolumn{9}{|c|}{$\begin{array}{l}\text { Levene's Test } \\
\text { for Equality of } t \text { Test for Equality of Means } \\
\text { Variances }\end{array}$} \\
\hline & & \multirow[t]{2}{*}{$F$} & \multirow[t]{2}{*}{ Sig. } & \multirow[t]{2}{*}{$t$} & \multirow[t]{2}{*}{$d f$} & \multirow[t]{2}{*}{$\begin{array}{l}\text { Sig. } \\
\text { (2-tailed) }\end{array}$} & \multirow[t]{2}{*}{$\begin{array}{l}\text { Mean } \\
\text { Difference }\end{array}$} & \multirow[t]{2}{*}{$\begin{array}{l}\text { Std. Error } \\
\text { Difference }\end{array}$} & \multicolumn{2}{|c|}{$\begin{array}{l}95 \% \\
\text { Confidence } \\
\text { Interval of the } \\
\text { Difference }\end{array}$} \\
\hline & & & & & & & & & Lower & Upper \\
\hline \multirow[t]{2}{*}{$\begin{array}{l}\text { Pretes } \\
t\end{array}$} & $\begin{array}{l}\text { Equal } \\
\text { Variances2 } \\
\text { Assumed }\end{array}$ & 6.25 & .01 & $\begin{array}{l}-2.0 \\
7\end{array}$ & 28 & .04 & -1.60 & .77 & -3.18 & -.01 \\
\hline & $\begin{array}{l}\text { Equal } \\
\text { Variances } \\
\text { Not } \\
\text { Assumed }\end{array}$ & & & $\begin{array}{l}-2.0 \\
7\end{array}$ & $\begin{array}{l}22.5 \\
0\end{array}$ & .05 & $-1 . .60$ & .77 & -3.18 & .000 \\
\hline
\end{tabular}

Because the Sig. value for the Levene's test is smaller than $.05($ Sig. $=.01)$, for the $t$ test results, the lower row (i.e., equal variances not assumed) and the values therein should be used. According to Table 3, there was a statistically significant difference in the posttest scores for Group A $(M=15.53, S D=2.58)$ and Group B $(M=$ $17.13, S D=1.50), t(28)=-2.07, p=.05$ (2-tailed). This was so because the $p$ value was equal to the specified level of significance (i.e., .05). If the $p$ value were greater than the .05 , the conclusion would be that the two 
groups were not significantly different in terms of their writing accuracy after the implementation of the experiment. One could, therefore, infer that dictation was more effective than dicto-comp when it comes to the improvement of writing accuracy.

\subsubsection{Results for the Second Research Question}

The second research question of the current study was formulated to investigate whether dicto-comp writing influenced the degree of accuracy of the writing skill of adult Iranian EFL learners. To this end, a paired samples $t$ test was conducted. Table 3 displays the descriptive statistics for this analysis:

Table 3. Descriptive statistics for comparing pretest and posttest scores of Group A

\begin{tabular}{lllll}
\hline & $N$ & Mean & Std. Deviation & Std. Error Mean \\
\hline Group A Pretest & 15 & 16.73 & 2.08 & .53 \\
Group B Posttest & 15 & 15.53 & 3.58 & .66 \\
\hline
\end{tabular}

It can be seen that in the Group A, the mean score of the learners on the pretest $(M=16.73)$ was surprisingly larger than that of the posttest $(M=15.53)$. To find out whether the difference was statistically significant, the following $t$ test table had to be consulted:

Table 4. Results of the paired samples t test for comparing pretest and posttest scores of Group B

\begin{tabular}{|c|c|c|c|c|c|c|c|}
\hline & \multicolumn{4}{|c|}{ Paired Differences } & \multirow[b]{4}{*}{$t$} & \multirow[b]{4}{*}{$d f$} & \multirow[b]{4}{*}{ Sig. (2-tailed) } \\
\hline & \multirow[b]{3}{*}{ Mean } & \multirow[b]{3}{*}{ Std. Deviation } & \multirow[b]{3}{*}{ Std. Error Mean } & $\begin{array}{l}95 \% \text { Confidence } \\
\text { Interval of the } \\
\text { Difference }\end{array}$ & & & \\
\hline & & & & Lower Upper & & & \\
\hline & & & & & & & \\
\hline Pretest-Posttest & 1.20 & 3.05 & .78 & 2.89 & 1.52 & 14 & .15 \\
\hline
\end{tabular}

Given the fact that the $p$ value was greater than the specified level of significance $(.15>.05)$, it could be concluded that there was not a significant difference between the pretest scores of the learners in the Group A ( $M$ $=16.73, S D=2.08)$ and their posttest scores $(M=15.53, S D=2.58), t(14)=1.52$. Therefore, the third hypothesis which states that dicto-comp influence the degree of accuracy of the writing skill of Iranian EFL learners was rejected.

\subsubsection{Results for the Third Research Question}

The last research question of the present study intended to find out whether writing influences the degree of accuracy of the writing skill of adult Iranian EFL learners. Like the analysis performed for the second research question, a paired samples $t$ test was run to find an answer to the third research question. Table 5 displays the descriptive statistics for this analysis:

Table 5. Descriptive statistics for comparing pretest and posttest scores of Group B

\begin{tabular}{lllll}
\hline & $N$ & Mean & Std. Deviation & Std. Error Mean \\
\hline Group B Pretest & 15 & 16.54 & 1.88 & .48 \\
Group B Posttest & 15 & 17.13 & 1.50 & .38 \\
\hline
\end{tabular}

According to Table 5, in the Group B, the mean score of the learners on the pretest $(M=16.54)$ was less than their posttest mean score $(M=17.13)$. The $t$ test results in Table 6 will show whether the difference was statistically significant or not: 
Table 6. Results of the paired samples t test for comparing pretest and posttest scores of Group B

\begin{tabular}{|c|c|c|c|c|c|c|c|}
\hline & \multicolumn{4}{|c|}{ Paired Differences } & \multirow[b]{4}{*}{$t$} & \multirow[b]{4}{*}{$d f$} & \multirow[b]{4}{*}{ Sig. (2-tailed) } \\
\hline & \multirow[b]{3}{*}{ Mean } & \multirow[b]{3}{*}{ Std. Deviation } & \multirow[b]{3}{*}{ Std. Error Mean } & $\begin{array}{l}95 \% \text { Confidence } \\
\text { Interval of the } \\
\text { Difference }\end{array}$ & & & \\
\hline & & & & Lower Upper & & & \\
\hline & & & & & & & \\
\hline Pretest-Posttest & -.60 & 2.32 & .60 & -1.88 & -1.00 & 14 & .33 \\
\hline
\end{tabular}

Because the $p$ value was greater than the alpha level $(.33>.05)$, it could be understood that there was not a significant difference between the pretest scores of the learners in Group B $(M=16.54, S D=1.88)$ and their posttest scores $(M=17.13, S D=1.50), t(14)=-1.00$.

$\mathrm{H}_{03}$ : Dictation does not influence the degree of accuracy of the writing of Iranian EFL learners.

\subsection{Results}

The overall conclusion to be drawn from the results of this study could be couched in the following terms: Although dicto-comp and dictation techniques did not lead to meaningful differences between the pretest and posttest writing accuracy scores of the two experimental groups, dictation was found to be significantly more beneficial to writing accuracy than dicto-comp.

As the texts revealed, applying dicto-comp and dictation - as two kinds of controlled writings - had an impact on the writing of adult L2 learners because controlled writing includes listening to the teacher who is reading a text, and taking notes, then creating a similar one, or writing the sentences down immediately. For covering these steps, the learners are to first, listen very well and then, reevaluate their knowledge and use it in a correct form while the read text is a pattern for them to follow.

As to the second question and the second null hypothesis, dicto-comp did not influence the degree of accuracy of the writing of Iranian EFL learners Group A $(M=16.73, S D=2.08)$ and their posttest scores $(M=15.53, S D=$ $2.58), t(14)=1.52, p=.15)$. The results showed that the second null hypothesis is not rejected:

\section{Discussion}

The main aim of this study was to compare the accuracy of the writing of adults Iranian L2 learners practicing through dicto-comp in Group A and dictation in Group B.

Referring to the first question of the study about the difference between the texts produced by the participants practicing writing through dicto-comp versus dictation in aspect of accuracy, the results (see Table 3) showed that there was not a statistically significant difference in the pretest scores for Group A $(M=16.73, S D=2.08)$ and Group B $(M=16.54, S D=1.88), t(28)=.27, p=.78$ (2-tailed). This was so because the $\mathrm{p}$ value was greater than the specified level of significance (i.e., .05). If the $p$ value were less than the alpha level (i.e., the level of significance), the conclusion would be that the two groups were not at the same level of writing accuracy prior to the experiment. Also, the results (see Table 5) of the comparison of the results of the posttests obtained from Groups A and B indicated that there was a statistically significant difference in the posttest scores for Group A $(M=15.53, S D=2.58)$ and Group B $(M=17.13, S D=1.50), t(28)=-2.07, \mathrm{p}=.05(2$-tailed). This was so because the $\mathrm{p}$ value was equal to the specified level of significance (i.e., .05). If the $\mathrm{p}$ value were greater than the .05 , the conclusion would be that the two groups were not significantly different in terms of their writing accuracy after the implementation of the experiment. One could, therefore, infer that dictation was more effective than dicto-comp when it comes to the improvement of writing accuracy.

Considering the second question of the study which investigated if dicto-comp influenced the writing of adult L2 learners in case of accuracy, the results which indicated and compared the results of the pretest and posttest of Group A which practiced writing through dicto-comp pointed to the fact that the $\mathrm{p}$ value was greater than the specified level of significance $(.15>.05)$, so it could be concluded that there was not a significant difference between the pretest scores of the learners in Group A $(M=16.73, S D=2.08)$ and their posttest scores $(M=15.53$, $S D=2.58), t(14)=1.52$.

To reply the third question which attempted to find whether the use of dictation had impact on the level of accuracy of the writing of adult L2 learners, the results of the pretest and posttest of Group B in which the 
participant were exposed to dictation indicated that the $\mathrm{p}$ value was greater than the alpha level $(.33>.05)$, so it could be understood that there was not a significant difference between the pretest scores of the learners in Group B $(M=16.54, S D=1.88)$ and their posttest scores $(M=17.13, \mathrm{SD}=1.50), t(14)=-1.00$.

It can be assumed that practicing writing in dicto-comp puts the adult L2 learners under pressure to comprehend the text read. Most of their concentration goes for understanding the content. Although the text was read twice by the teacher, the learners did not seem to pay enough attention to the structures. After the listening to the text, they could write the texts by themselves, but the structures were not as accurate as they had to be, so one can conclude that dicto-comp cannot be beneficial enough to improve the writing of adult L2 learners.

The result of the third hypothesis are in line with that of Oller (1979) who believes that the reason for considering dictation as a successful controlled writing is that in that learners can show what they really know about the L2 and how they use it in their real life. Oller also emphasizes that dictation is successful because listeners understand what they hear and then they combine that and produce piece of writing - they do it by recalling the previous knowledge in their mind.

It can be concluded that although dictation and dicto-comp techniques did not lead to meaningful differences between the pretest and posttest writing accuracy scores of the two experimental groups, dictation was found to be significantly more beneficial to writing accuracy than dicto-comp.

\section{Implications of the Study}

There are some implications arising from the findings and conclusion of the study for language teachers and materials developers. Although dictation used to be one of the most common ways of practicing writing and checking spelling power of learners in both L1 and L2 in elementary schools, junior high schools, and senior high schools, it is not known as a popular way to practice writing and spelling in English classes in institutes-it can be brought back to classes by asking the language teachers and learners in language institutes. The main purpose of L2 teaching and learning is having the ability to communicate, so one needs to be able to comprehend the partner's idea and also express his or her thought in oral or written form. According to Brown (2000), when one is asked "Do you speak English?" it means if one can start and handle a conversation from the beginning to the end. Besides, the objectives of CLT include functional and as well as linguistics objectives (Brown, 2000). Briefly, all these can make one convinced that using dictation and dicto-comp in the process of L2 learning can be useful and fruitful because of their positive effect, first, on comprehension and, then, on expression and production ability of L2 learners.

As learning an L2 has been getting more and more popular since the eagerness for immigration and having the ability to create connection with foreigners have been increased. This popularity even tempts the elderly to attend L2 classes to learn or improve their knowledge. Working with adults gives the teacher this experience that writing seems difficult and sometimes unnecessary to adult L2 learners. It is seen that adult L2 learners rank writing as the least important skill. It is because they do not know enough about the important effect of writing on the other skills (e.g., reading and speaking). The results of this study give a broad attention to teachers and materials developers. Dictation still can be considered as an aid or device which can empower the weak points in the writing of L2 learners in aspect of spelling, structure, and sentence building. The present study was done among aged L2 learners who are growing in number these days. Applying dictation in adult L2 learners (aged over 55) encourages them to try to comprehend the text and create their own texts. While they are listening and keeping the chunks in their mind, they are practicing their minds to remember things easier. The short-term memory is also enhanced, as L2 learners practice retaining meaningful phrases or whole sentences before writing them down (Nation, 1991). Morris (1983) notes that dictation trains students to develop more awareness with context clues. It is worth occupying enough time of a lesson plan of an L2 class according to the level and grade of the class and the need of the learners in the specific class. It is the role of the teacher to diagnose the main problem and also the source of that. Utilizing a correct text in a the level of the student in one class can make the eagerness of the learners twice as more to some degree that the learners voluntarily ask for writing dictation. By observing the increase of the capability in their own writing, L2 learners show enthusiasm in spending part of the time of the class writing dictation.

Not only teachers but also materials developers had better consider dictation as a part of the books released in the educational system as well as language institutes. The most popular books these days include writing as a productive part after some practices and tasks which work as input. Dictation can be considered as a drill for the learners to get ready to produce a text. As mentioned in chapter 2, Krashen (2003) believes in the use of dictation and controlled writing in university classrooms because in using this method to improve writing, considering the skill and range of class is not needed. The use of dictation can provide some benefits for university EFL 
classroom management, too. Dictation can be used successfully regardless of class size or range of skill. Because here they work together and use grammatical text to complete the dictation. Alkire (2002) claims that dictation also helps learners to practice and repeat the correct and grammatical forms/texts, and also they can practice other skills during doing dictation practices.

\section{Limitations of the Study}

This study could remind us to use dictation as a controlled writing to help the improvement of L2 learners, but it is not fair to deny the limitations existing in that. The main limitation goes to the factors inspected through this study. A piece of writing can be checked in aspect of accuracy, fluency, and grammatical complexity. The present study just explored the effect of controlled writing on the writing of adults in aspect of accuracy.

The other limitation which can be removed in the further studies is gender. The present study focused on female adult L2 learners, whereas comparing the role of dictation and dicto-comp in the progress of writing of male adult L2 learners could be beneficial.

The third limitation which the researcher faced was time. The number of the sessions considered to apply this study was 10 one-hr sessions - it could have been more though. Specially, the needed time for practicing dicto-comp could have been, at least, 20 sessions to have enough time prior to the study to present the aim of the activity and the procedures to get the aim, letting the learners feel progressed and relaxed through the study because presenting an almost new approach to the L2 learners, specially adults, would be one of the time-consuming activities. This point was considered as the main reason for rejecting the impact of dicto-comp on the writing skill of adult L2 learners. Lack of sufficient time for presenting the aim, procedures, and benefits of the present study on the writing of the participants caused the research to lose some of the useful potential steps to keep the participants convinced and motivated through the end of the study.

\section{References}

Alkire, S. (2002). Dictations as a language learning device. Retrieved from http://www.iteslj.org/techniques/Alkire-dictation.html

Aukerman, M. (2006). Who's afraid of the big "bad answer"? Educational Leadership, 64, 37-1.

Baker, S., Gersten, R., \& Graham, S. (2003). Teaching expressive writing to students with learning disabilities.

Barrent, M. A. (1989). Writing as a process. French Review, 1, 31-44.

Birdsong, D., \& Mollis, M. (2001). On the evidence for maturational effects in second language acquisition. Journal of Memory and Language, 44, 235-249. http://dx.doi.org/10.1006/jmla.2000.2750

Brandenburg, M. L. (2002). Advanced math? Write! Educational Leadership, 30, 67-68.

Brown, H. D. (2001). Teaching by principles (2nd ed.). New York: Longman

Chastain, K. (1980). Native speaker reaction to instructor - identified student second - language errors. The Modern Language Journal, 64(2), 210-215. http://dx.doi.org/10.1111/j.1540-4781.1980.tb05187.x

Dickson, S. V., Kameenui, E. J., \& Simmons, D. C. (1998). Text organization: Research bases. What reading research tells us about children with diverse learning needs. Bases and Basics, 6, $239-277$.

Dornyei, Z. (2001). Teaching and researching motivation. Harlow, England: Longman.

Eisterhold, J. C. (1990). Reading-writing connections: Toward a description for second language learners. Second Language Writing: Research Insights for the Classroom, 30(5), 88-101. http://dx.doi.org/10.1017/CBO9781139524551.010

Frey, N., \& Fisher, D. (2007). Reading for information in elementary school. Upper Saddle River, NJ: Merrill Prentice Hall.

Gammill, D. M. (2006). Learning the write way. The Reading Teacher, 59, 754-762. http://dx.doi.org/10.1598/RT.59.8.3

Graham, S., \& Hebert, M. (2010). Writing to read: Evidence for how writing can improve reading: A report from Carnegie Corporation of New York. New York: Carnegie Corporation of New York.

Graham, S., \& Perin, D. (2007). Writing next: Effective strategies to improve writing of adolescents in middle and high schools. A report to Carnegie Corporation of New York. Washington, DC: Alliance for Excellent Education.

Hurst, B., Fisk, C., \& Wilson, C. (2006). Beyond reading logs: Read, respond, revisit, discuss. Journal of Reading 
Education, 31, 37-41.

Janopoulos, M. (1989). Reader comprehension and holistic assessment of second language writing proficiency. Written Communication, 6(2), 218-237. http://dx.doi.org/10.1177/0741088389006002005

Ilson, R. (1962). The dicto-comp: Specialized technique for controlling speech and writing in language learning. Language Learning, 12(4), 299-30. http://dx.doi.org/10.1111/j.1467-1770.1962.tb01265.x

Krashen, S. (2003). Explorations in language acquisition and use: The Taipei lectures. New York: Heinemann.

Lenneberg, E. H. (1967). Biological foundations of language. New York: Wiley.

Masgoret, A. M., \& Gardner, R. C. (2003). Attitudes, motivation, and second language learning: A meta-analysis of studies conducted by Gardner and Associates. Language Learning, 53(5), 167-210. http://dx.doi.org/10.1111/1467-9922.00227

Mezirow, J. (1991). Transformative dimensions of adult learning. San Francisco: Jossey-Bass.

Morris, S. (1983). Dictation: A technique in need of reappraisal. ELT Journal, 37(3), 121-126. http://dx.doi.org/10.1093/elt/37.2.121

Nation, P. (1991). Dictation, dicto-comp, and related techniques. English Teaching Forum, 29(4), 12-14.

Oller, J. W. (1979). Language tests at school: A pragmatic approach. Longman, London.

Olsen, C. B., \& Land, R. (2007). A cognitive strategies approach to reading and writing for English language learners in secondary school. Research in the Teaching of English, 41(3), 269-303.

Owens, K. N. (1970). Pattern and structure in Western territorial politics: The western historical quarterly. Content reading instruction in the primary grades: Perceptions and strategies. Reading Teacher, 45(4), 298-307. http://dx.doi.org/10.2307/967484

Paulston, C. B. (1992). Linguistic and communicative competence: Multilingual matters. Cambridge, MA: Harvard Education Press.

Phillips, W. D. (2011). William D. Phillips-Autobiography. Retrieved August 31, 2013, from http://nobelprize.org/nobel prizes/physics/laureates/1997/phillips.html

Raimes, A. (1983). Techniques in teaching writing. Oxford: Oxford University Press.

Shanahan, T. (2006). Relations among oral language, reading, and writing development. In C. A. MacArthur, S. Graham, \& J. Fitzgerald (Eds.), Handbook of writing research (pp. 171-186). New York, NY: Guilford Press.

Stansfield, C. W. (1985). A history of dictation in foreign language teaching and testing. Modern Language Journal, 69(2), 121-128. http://dx.doi.org/10.1111/j.1540-4781.1985.tb01926.x

Takeuchi, O. (1997). Dictation: Is it really effective for language teaching? Kansai University Audio Visual Education, 20, 155-161.

Vacca, R. T., \& Vacca, J. L. (2004). Content area reading: Literacy and learning across the curriculum (8th Ed.). Boston: Pearson, Allen \& Bacon.

\section{Copyrights}

Copyright for this article is retained by the author(s), with first publication rights granted to the journal.

This is an open-access article distributed under the terms and conditions of the Creative Commons Attribution license (http://creativecommons.org/licenses/by/3.0/). 